\title{
Competition as a Response Strategy to Globalization by Manufacturing Firms in Kenya
}

\author{
Solomon Kinyanjui ${ }^{1}$, Margaret A. Oloko ${ }^{2}$, Hazel G. Gachunga ${ }^{1} \&$ Beatrice G. Gathondu $^{3}$ \\ ${ }^{1}$ School of Human Resource Development, Jomo Kenyatta University of Agriculture \& Technology, Nairobi, Kenya \\ ${ }^{2}$ Department of Commerce and Economic Studies, Jomo Kenyatta University of Agriculture and Technology, Nairobi, \\ Kenya \\ ${ }^{3}$ Applied Science, Jomo Kenyatta University of Agriculture and Technology, Karen Campus, Nairobi, Kenya \\ Correspondence: Solomon Kinyanjui, Business Administration, School of Human Resource Development, Jomo \\ Kenyatta University of Agriculture \& Technology, Nairobi, Kenya. E-mail: kinyanjui@solsinclinations.com
}

Received: October 11, 2014

Accepted: November 13, 2014

Online Published: November 16, 2014

doi:10.5430/ijba.v5n6p48

URL: http://dx.doi.org/10.5430/ijba.v5n6p48

\begin{abstract}
Globalization affects local and international firms in many ways. Studies have shown that factors in the internal as well as external environments of firms influence the rate to which globalization will affect them. On the local scene however, no known studies have been done on the response of Kenyan manufacturing firms to counter globalization. In addition, since the concept of globalization is multidimensional and its influence is varied in nature, this study aimed at investigating how manufacturing firms in Kenya have responded to probable pressure from the forces of globalization in order to sharpen their competitiveness. Cross sectional survey design was adopted for the study. The population for the study was the 735 manufacturing firms in Kenya. The target population of the study was CEOs/MDs and their deputies from 545 manufacturing companies in Nairobi and Athi River. Stratified sampling technique was used to categorize the targeted manufacturing firms into sectors where purposive sampling technique was used to sample the respondents for the study. A total of 100 firms from the 14 sectors were targeted by the study out of which 80 responded giving a response rate of $80 \%$. Questionnaire was used to collect primary data. Regression and correlation analysis was done to test the relationship between the study variables. On the relationship between competition and globalization in manufacturing firms in Kenya, the study found that $60 \%$ of the respondents indicated to a large extent exploring other markets is a competitive strategy of responding to globalization, 55\% of the respondents indicated that to a large extent increasing the range of products produced is a competitive strategy of responding to globalization, $40 \%$ of the respondents indicated that to a very large extent innovations are competitive strategies of responding to globalization. The findings from the correlation analysis showed that globalization has a positive relation with competition with a Pearson's Correlation Coefficient of 0.558 and 0.021 level of coefficient. The null hypothesis that there is no significant relationship between globalization and competition was therefore rejected. The study concluded that manufacturing firms in Kenya have adopted competition as response strategies to globalization. The study recommended that manufacturing firms should reduce the direct cost such as energy while improving the market share.
\end{abstract}

Keywords: competition, globalization

\section{Introduction}

Globalization has come with both positive as well as negative effects on the way people conduct businesses across the world (Ray, 2007). In response to the outcomes impacted by globalization, firms that have re-organized themselves strategically have been found to achieve competitive advantage. According to Parker (2005), Ervin and Smith (2008) and Ray (2007) many firms have achieved competitiveness through product branding and adoption of new ways of approaching markets.

According to Peltonen, Skala, Alvaro and Gabor (2008), import competition among manufacturing firms has led to negative impact on firm's profitability. Myatt (2006) notes that $21^{\text {st }}$ century businesses should not overlook taking 
advantage of the benefits inherent in globalization. He emphasizes that through globalization, firms can reposition themselves at a higher competitive level. Myatt adds that through globalization the international business boundaries have been opened thus allowing the movement of goods from one nation to another without many hindrances. Ervin and Smith (2008) further support this that through globalization, import and export business of nations has increased significantly. Other advantages of globalization to businesses are increased customer base courtesy of targeting international customers, stabilizing commodity prices, increased opportunities for a business to expand its revenues (Myatt, 2006), enhanced relationship and goodwill between nations and the ability to import expertise (Parker, 2005).

Several factors have led to globalization. Rowbotham (2000) asserts that a well functioning financial system adopted across the world after creation and easy supply of money across national economies; international trade imbalance; acute debt bothering the developing nations; and flexibility in the flow of financial capital are key drivers to globalization. Mussa (2000) on the other hand argues that opening up of national boundaries due to tastes, technology, and public policy, which interact in important ways has contributed to globalization. He presents political, economic and social factors as key drivers of globalization. Social factors such as tastes of people attract economic benefits to those who respond to such tastes through using appropriate technology to either produce or supply to such tastes.

Globalization has been seen to have significant effects on manufacturing firms across the world - whether positive or negative. This is because manufacturing firm's deal with the production of goods. Successful multinational firms do not only venture in any global market but also identify the opportunities resulting in a global market, then formulate a strategy that will enable the firm venture successfully. Therefore, a global strategy is a guide giving organizations ways to penetrate in the global markets. Livesey (2006) defines manufacturing as "the transformation of raw materials into finished products." This explains manufacturing firms as those, which handle raw materials and change these raw materials into finished goods. Therefore, given the current opening of global markets, manufacturing firms have been exposed to certain challenges that trigger the management to use diverse methods in response to this competition.

Firms operating in the same country and industry respond to globalization in very different ways. Empirical work using micro-level data on firms or plants initially highlighted this contrast for export decisions and how this decision correlates with observable firm performance measures such as size and productivity: only a subset of relatively bigger and more productive firms export. Bloom, Draca and Van-Reenen (2008) document a relationship between changes in the trading environment, firm innovation and skill upgrading, but on the import competition side. Firms in European industries most exposed to increased import competition from China respond by increasing their innovation and information technology intensity (Bernard, Jensen \& Schott, 2006). Subsequent work has documented a wide ranging set of other responses to globalization that consistently vary across firms in the same country and industry, and are also strongly correlated with firm level performance measures: the number and location of export destinations, entry and exit from the domestic market, the range of products produced, the international organization of production and innovation activities such as research and development.

\subsection{Statement of the Problem}

For a long time Kenya has been known as a nation with adequate political stability compared to its neighbours making it a favourable state to invest in (Muhoro, 2011). The country's weak unions and less saturated market also make Kenya a favourable place for investments (Firestone, Butler, Hardy \& Karlin, 2009). As such, Kenya has attracted many international investors, who have caused competition in the local markets. This forms one of the explanations why the Kenyan market has been filled with products most of them from overseas markets particularly Asian countries like China and India (Miriga, 2010; Nyabiage, 2012). On the flipside however, with the increase in people's and societies' interconnectedness resulting from globalization, there has been continued threats to the stability of Kenya's market environment. These threats have manifested in the form of terrorism and kidnappings of both local and foreign nationals on Kenyan soil.

In Kenya, manufacturers have also had a fair share of challenges. They have struggled to attain a competitive cutting edge against multinational firms operating in the local market (Nyabiage, 2012). Even agricultural-produce manufacturers, though expected to perform well locally due to adequate availability of raw materials, have faced rapid competition from imported products. These challenges have affected local manufacturers trading internationally and locally. The statistics on the contribution of Kenya Gross Product by activity measured in market prices show that the contribution of the manufacturing sector is on the uptrend (KAM, 2011). On the side of growth rates by industry, 
statistics show that the growth of the manufacturing sector has been fluctuating with 2009 registering the lowest growth of 1.3\% from the previous 3.5\%, which later recovered in 2010 and 2011 (KAM, 2011).

There is a possibility that these fluctuations are caused by intensifying globalization and its effects on manufacturing firms. While a number of literary articles present discussions on globalization and its influence on business, little has been done to try to understand how firms are coping or responding to the ever-changing nature of globalization. According to Honkala, Goldstein, Thul, Baptist and Grugan (1999), inadequate response to the globalization phenomenon has made some countries like USA to observe increases in poverty levels. They further assert that this increase in levels of poverty has seen the gap between the rich and poor widening as poor people are denied better payment and jobs while higher profits and reduced costs continues to be experienced by corporation owners. Of particular importance is that such information in regard to manufacturing firms in Kenya is truly lacking. The reality is that globalization is an unavoidable phenomenon, and as such, this study seeks to establish the response of Kenyan manufacturing firms to globalization. The objective of the study was to explore the relationship between competition and globalization in manufacturing firms in Kenya.

\subsection{Study Hypothesis}

H0: There is no significant relationship between competition and globalization.

\section{Literature Review}

\subsection{Five Forces of Competitive Position Model}

The study engaged Michael Porter's five forces of competitive position model to discuss and make meaning in the findings of the study. This model presents a simple way of analyzing the competitive strength of a firm or organization (Enz, 2010). According to Roy (2009), the five forces of competition championed by Porter are: existing competitive rivalry between firms; threat of new market entrants; bargaining power of buyers; power of suppliers; and threat of substitute products (including technology change), Figure 1.

Competitive rivalry also affects the success of firms in their competitive environments. The number of competitors as well as their capabilities and magnitude will determine the intensity of rivalry. Industry rivalry is considered high when: customers have low switching costs; there are high exit barriers; the industry is growing; and there are high fixed costs that lead to high production and lower prices (Hill \& Jones, 2010). Rivalry has been seen to constitute price wars, advertising wars and difficulty in competing (Enz, 2010).

The bargaining power of buyers is the potential with which buyers will bargain down the prices charged by firms or the power by which they will demand better quality and service of products (Hill \& Jones, 2010). When the buyers have a strong bargaining power, they will be few in number. Since they have a high purchasing power, they will purchase in large (bulk) quantities. They are well informed about the product and the market; the cost of switching to a competitor's product is low; when the product is not differentiated; or when the shipping cost is low. In this way, buyers are identified as a threat to the firm.

The bargaining power of the suppliers is considered as the ability of suppliers to increase prices of inputs. Strong suppliers deny firms of their profits through increasing their costs. Suppliers gain a higher bargaining power when there are few substitutes; they cannot be substituted; they are unique; they have high switching cost; or they are a significant input to the buyers' products. In this case the suppliers pose a threat to the profits of the firm since they dictate to the firm (Hill \& Jones, 2010).

Threat of substitute products considers how easily the customers of a firm can shift to competitor products (Roy, 2009). In case a firm's customers can easily switch to competitor products, it means that the firm is likely to loose its market grip, something that will significantly affect the firm's business activities and revenue, and, depending on the magnitude of the switch, failure of the firm. A successful firm is one that exists in a market where the threat to substitute products is very low. 


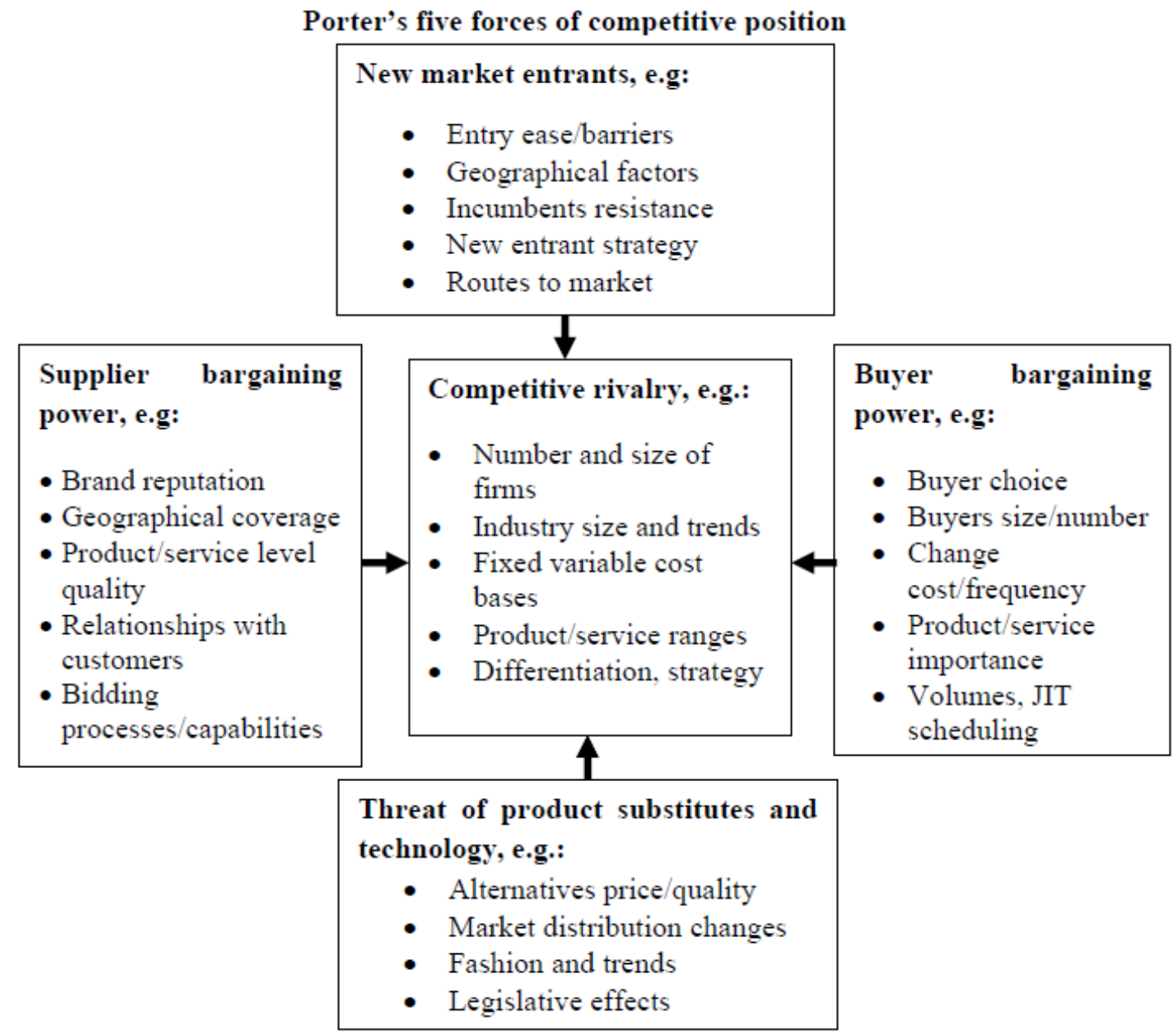

Figure 1. Porter's five forces of competitive position

Adapted from: Enz (2010).

Since globalization opens the boundaries of trade among nations and firms from different regions of the world, these five forces of competition model significantly helped explain the study variables under a globalized market. For instance, globalization has seen increased rivalry due to increased competition. It has also reduced the entry barriers to several areas of business. This model therefore played a significant role in discussing the findings of this study.

\subsection{Competition and Globalization}

Hannah and Camilla (2008) did a study to investigate the branding strategies of MNCs in international markets. Two research questions were addressed: how can the branding strategies of MNCs in international markets be described and how can the factors determining MNCs' choice of branding strategies in international markets be described. Two qualitative case studies of well-known MNCs, Proctor \& Gamble and Sony Ericsson were conducted; the first an example of a company with a product brand strategy and the latter one with a corporate brand strategy. The findings of the study revealed that MNCs use either a product brand strategy, or a corporate brand strategy. However, there may be mixtures of the two types, but emphasis is typically on one of them. A product brand strategy is characteristically used when a company offers multiple products within different business segments, and when there are several different target groups. With a corporate brand strategy, the corporate name and the brand are the same. There is typically a master brand which has the same name as the corporation, and which may have additional sub-brands. It was found that the factors determining the branding strategy in international markets are stakeholder interests, corporate image and reputation, market complexity, as well as marketing costs.

Uslay (2005) did a study on the role of pricing strategy in market defense. He attempted to shed light on the role that price plays in preemptive and post-entry market defense of firms. As such, the questions tackled included: how 
effective is price as an entry-deterrence tool; in conjunction with firm and market specific barriers to entry; and as a post-entry retaliation mechanism? What are the facilitating conditions for limit, aggressive (predatory), competitive and supra-competitive pricing? What are the (long-term) consequences of these strategies? Dynamic process model was adopted for the study where hypotheses were tested in a key network industry - the airline industry. Building upon the advantages of multiple methods a triangulation, the study found that both limit pricing and predatory pricing can serve as effective strategies for the incumbents' market defense. Predatory use of pricing in network industries may diminish consumer welfare. Results also suggest that firm specific barriers have a more significant role in market defense than market specific barriers.

According to Friedman (2006), globalization leads to increased competition due to the introduction of products from countries all around the globe with ever-increasing lower prices. It used to be that firms would only compete against firms that were geographical close and of similar size. Now with globalization, companies are competing against other companies all around the globe and all of different sizes. This growing competition also leads to what is known as commoditization; where there are so many companies with so many similar goods that a company's specific good becomes a commodity in its market because there are so many others just like it. The rate at which commoditization has occurred was unanticipated as well; just a few years ago organizations were competing against a few companies with some similar products (Friedman, 2006).

Studies have examined the heterogeneity in firms' responses to product competition in terms of changes in their productivity (the other part of "capability"). Aghion et al. (2005) hypothesized that within-industry variation in firm performance should increase with competition, as those firms further from the frontier and in regions with poorer business institutions invest less while those close to the frontier will invest more in new technologies and production processes. They analyze a three-digit industry data available for all the states in India for the period 1980-97 and find that entry liberalization (de-licensing) led to an increase in within-industry inequality in output, labour productivity and total factor productivity.

Sabirianova, Svejnar and Terrell (2005) also find support for heterogeneous effects of firm entry on firm performance in Russian and Czech industrial firms. They find that entry by foreign firms in a given industry has a positive effect on the productivity of foreign firms (which are at or close to the frontier) but a negative effect on the productivity of domestic firms (which are laggards compared with foreign firms). This study seeks to find out whether competition has been adopted as a response strategy to the effects of globalization.

\section{Methodology}

This study was carried out in manufacturing companies registered with KAM in Nairobi County and Athi River in Mavoko Sub-County of Machakos County. The study targeted the senior most ranking officer (MDs or CEOs) and their deputies. The study targeted those manufacturing companies who are registered with KAM and are based in the selected regions. The target population for the study was therefore $560(80 \%$ of 700$)$ manufacturing companies. The study targeted 100 companies in the following sectors: building, mining and construction; chemical and allied; energy, electrical and electronics; fresh produce; food and beverage; leather and foot ware; metal and allied; paper and board; pharmaceutical and medical equipment; plastics and rubber; services and consultancy; textiles and apparels; and timber, wood and furniture. A total of 80 companies participated in the study. Questionnaires were used as instrument for data collection. Both quantitative and qualitative data analysis techniques were used. Quantitative data was analyzed using descriptive statistics while qualitative data was analyzed thematically. Inferential statistics such as correlation and regression analysis were used to test on the relationship between the variables of the study.

Linear regression model was used in the study

$$
\mathrm{Y}=\beta_{0}+\beta_{1} \mathrm{X}_{1}+\varepsilon
$$

Where:

$\mathrm{Y}$ is the dependent variable (Globalization)

$\mathrm{X}$ is the independent variable, i.e.

$\mathrm{X}_{1}$ - Competition

$\beta_{i(i=l)}$ was the parameters associated with the corresponding independent variable that was estimated (partial regression coefficients)

$\beta_{0}$ is the intercept 
$\varepsilon$ is the error variability (error term)

\section{Findings of the Study}

The study adopted factor analysis in order to reduce the number of indicators or factors under each research variable and retain the indicators capable of explaining the responses to globalization adopted by manufacturing firms in Kenya. The retained factors had loading values of above 0.4 and were used for further analysis. Hair et al. (1998) recommends use of factors with factor loading above 0.4. This is also supported by Tabachnick and Fidell (2007) using more stringent cut offs going from 0.32 (poor), 0.45 (fair), 0.55 (good), 0.63 (very good) or 0.71 (excellent).

To measure the reliability of the gathered data, Cronbach's alpha was used. Cronbach's alpha is a coefficient of reliability that gives an unbiased estimate of data generalizability (Zinberg, 2005). An alpha coefficient of 0.70 or higher indicated that the gathered data is reliable as it has a relatively high internal consistency and can be generalized to reflect opinions of all respondents in the target population (Zinbarg, 2005). The following sub-sections present factor analysis for the indicators of competition.

Table 1 shows Cronbach's alpha of all indicators for competition. Cronbach's alpha results in the component column were computed using results of all indicators. The results revealed that all the indicators/factors had a loading more than 0.4 .

Table 1. Competition reliability and factor analysis results

\begin{tabular}{lcc}
\hline & Component & Cronbach Alpha \\
\hline Focused low cost strategy & .879 & .834 \\
Exploring other markets & .864 & .751 \\
Overall low cost provider strategy & .716 \\
Innovations & .693 \\
Broad differentiation strategy & .637 \\
Focused differentiation strategy & .495 \\
Increasing the range of products produced &
\end{tabular}

Table 1 shows that Cronbach's alpha result of all competition indicators was 0.834 and the factor loading results were between 0.495 and 879 . This implies that all the indicators were retained for further analysis. Using all the competition indicators, the value of Cronbach's alpha was computed again and generated similar value of 0.834 . This indicated that data collected using all the competition indicator values were reliable since the Cronbach's alpha value was above 0.70 . The study hence deduced that all the seven competition indicators were reliable in determining competition as a response to globalization. These indicators were later used for further analysis.

Descriptive statistics were used to describe the basic features of the data in the study. They provide simple summaries of the sample and measures. Descriptive statistics such as frequencies and percentages were used to analyze the data.

Table 2. Competition versus globalization as a threat

\begin{tabular}{llrlrr}
\hline \multicolumn{6}{c}{ Group Statistics } \\
\hline \multirow{2}{*}{ COMPETITION } & THREAT & N & Mean & Std. Deviation & Std. Error Mean \\
& NOT A THREAT & 8 & 13.5603 & 1.46838 & .51915 \\
& THREAT & 31 & 14.0768 & 3.84317 & .69025 \\
\hline
\end{tabular}

Table 2 shows that difference between the two means is significant an indication that there is significant difference in competition and perception of globalization as a threat. This means that firms in high competition industries view globalization as a threat thus they have adopted competition strategies as a response to globalization. 


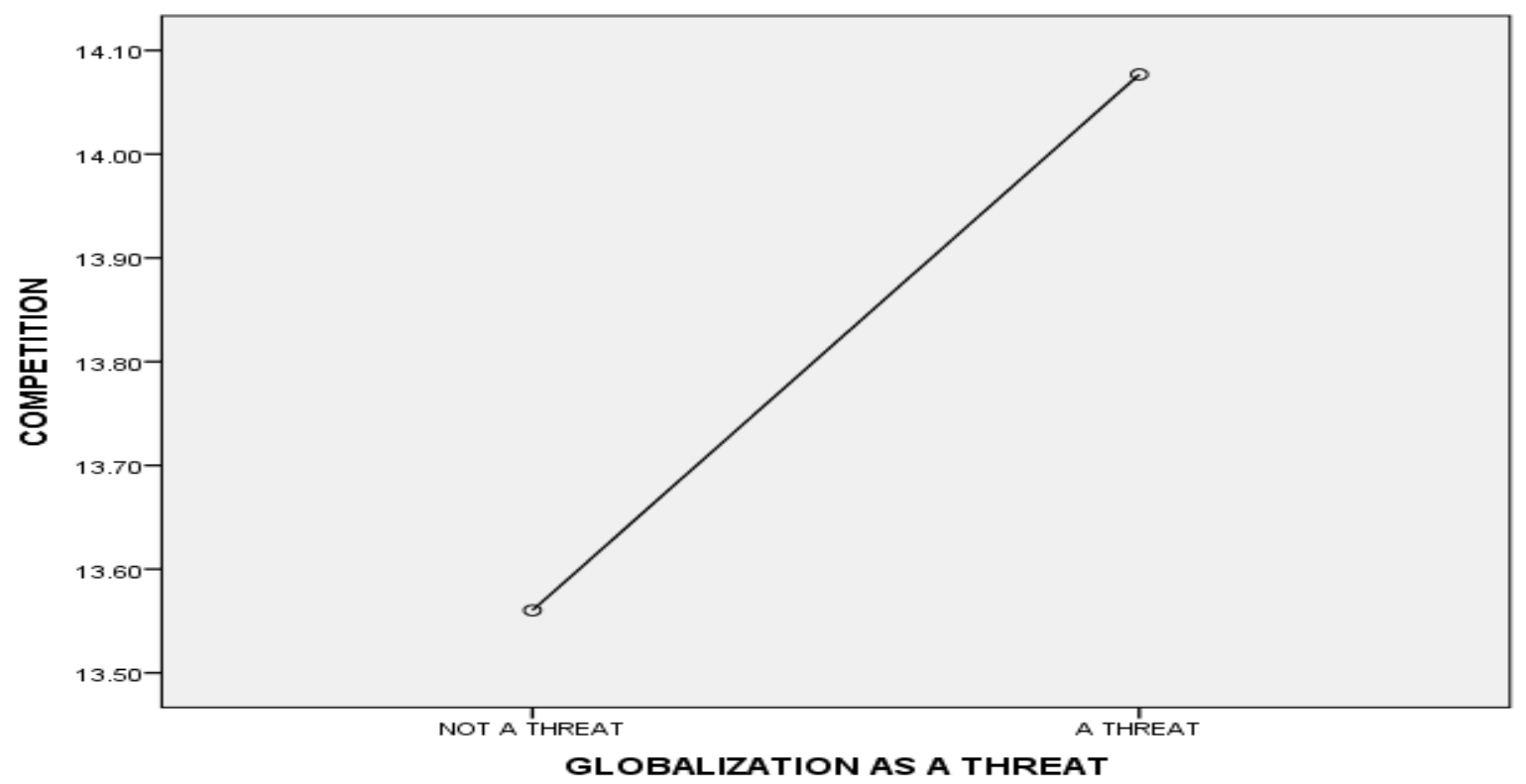

Figure 2. Competition versus globalization as a threat

Figure 2 shows that firms that were in highly competitive markets saw globalization as a threat while those in less competitive markets did not see globalization as a threat.

Table 3. T-test for equality of means for competition

\begin{tabular}{|c|c|c|c|c|c|c|c|c|}
\hline & & \multicolumn{7}{|c|}{ t-test for Equality of Means } \\
\hline & & \multirow[t]{2}{*}{$\mathrm{T}$} & \multirow[t]{2}{*}{$\mathrm{df}$} & \multirow[t]{2}{*}{$\begin{array}{c}\text { Sig. } \\
\text { (2-tailed) }\end{array}$} & \multirow[t]{2}{*}{$\begin{array}{c}\text { Mean } \\
\text { Difference }\end{array}$} & \multirow[t]{2}{*}{$\begin{array}{l}\text { Std. Error } \\
\text { Difference }\end{array}$} & \multicolumn{2}{|c|}{$\begin{array}{l}\text { 95\% Confidence } \\
\text { Interval of the } \\
\text { Difference }\end{array}$} \\
\hline & & & & & & & Lower & Upper \\
\hline \multirow{2}{*}{ COMPETITION } & $\begin{array}{l}\text { Equal } \\
\text { variances } \\
\text { assumed }\end{array}$ & -.370 & 37 & .713 & -.51656 & 1.39550 & -3.34410 & 2.31099 \\
\hline & $\begin{array}{l}\text { Equal } \\
\text { variances } \\
\text { not assumed }\end{array}$ & -.598 & 31.012 & .554 & -.51656 & .86369 & -2.27804 & 1.24493 \\
\hline
\end{tabular}

Table 3 shows that there is no significant difference in competition between companies that saw globalization as a threat and those, which did not at $95 \%$ level of confidence. This means that firms saw globalization as a threat thus they adopted competition as a response strategy to globalization. This is an indication that manufacturing firms have adopted competition as responses strategies as a response to pressure of globalization.

\subsection{Competition and Globalization}

To test on the relationship between competition and globalization in manufacturing firms in Kenya, the respondents were given different statements on the competitive strategies used by manufacturing firms. The findings of the study were as presented in Table 4. 
Table 4. Competition

\begin{tabular}{|c|c|c|c|c|c|c|}
\hline & $\begin{array}{l}\text { No extent } \\
\text { at all }\end{array}$ & $\begin{array}{l}\text { Small } \\
\text { extent }\end{array}$ & Neutral & $\begin{array}{l}\text { Large } \\
\text { extent }\end{array}$ & $\begin{array}{c}\text { Very Large } \\
\text { extent }\end{array}$ & Total \\
\hline Exploring other markets & $0.0 \%$ & $0.0 \%$ & $10.0 \%$ & $60.0 \%$ & $30.0 \%$ & $100.0 \%$ \\
\hline Innovations & $0.0 \%$ & $5.0 \%$ & $25.0 \%$ & $30.0 \%$ & $40.0 \%$ & $100.0 \%$ \\
\hline Focused low cost strategy & $0.0 \%$ & $10.0 \%$ & $30.0 \%$ & $30.0 \%$ & $30.0 \%$ & $100.0 \%$ \\
\hline $\begin{array}{l}\text { Increasing the range of products } \\
\text { produced }\end{array}$ & $5.0 \%$ & $0.0 \%$ & $5.0 \%$ & $55.0 \%$ & $35.0 \%$ & $100.0 \%$ \\
\hline Overall low cost provider strategy & $5.0 \%$ & $10.0 \%$ & $15.0 \%$ & $40.0 \%$ & $30.0 \%$ & $100.0 \%$ \\
\hline Focused differentiation strategy & $0.0 \%$ & $5.0 \%$ & $30.0 \%$ & $23.8 \%$ & $41.3 \%$ & $100.0 \%$ \\
\hline Broad differentiation strategy & $0.0 \%$ & $10.0 \%$ & $35.0 \%$ & $15.0 \%$ & $40.0 \%$ & $100.0 \%$ \\
\hline
\end{tabular}

The findings on Table 4 shows that $60 \%$ of the respondents indicated to a large extent exploring other markets is a competitive strategy of responding to globalization, $55 \%$ of the respondents indicated that to a large extent increasing the range of products produced is a competitive strategy of responding to globalization, $40 \%$ of the respondents indicated that to a very large extent innovations are competitive strategies of responding to globalization. From these findings, it is evident that one of the responses to globalization, which has been adopted by manufacturing firms in Kenya, is competition.

The respondents were further asked to mention other strategies adopted by manufacturing firms in Kenya to respond to globalization. The following were mentioned: upgraded website, corporate partnership with distributors around the globe \& branches in other African economies; infrastructure; information technology; social media marketing and branding; marketing segmentation; pricing strategies; market skimming; coming up with ISO friendly products and quality of goods. This is an indication that there are other responses to globalization other than adoption of technology, managerial innovation, resource management, distribution chain and completion that were not tested in the study.

\subsection{Correlation Analysis}

This study conducted correlation analysis to test on the strength of association/relationship between the study variables. Correlation is a measure of the relationship or association between two continuous numeric variables. It indicates both the direction and degree to which they vary with one another from case to case without implying that one is causing the other. Correlation analysis results give a correlation coefficient which measures the linear association between two variables (Crossman, 2013).

Values of the correlation coefficient range between -1 and +1 . A correlation coefficient of +1 indicates that two variables are perfectly related in a positive linear. A correlation of -1 indicates that two variables are negatively linearly related and a correlation efficient of 0 indicates that there is no linear relationship between two variables (Wond, 2012).

To clearly show the correlation analysis results, the study used scatter plots diagrams. A scatter plot diagram is a graph that shows the relationship between two quantitative variables. Scatter plots are used to investigate the possible relationship between two variables.

When interpreting the scatter diagram, the issues to $b$ considered includes:

If the points scatter in a band running from lower left to upper, there is a positive correlation (if $\mathrm{X}$ increase, $\mathrm{Y}$ increases).

If the points cluster in a band from upper left to lower right, there is a negative correlation (if $\mathrm{X}$ decreases, $\mathrm{Y}$ increases)

When a straight line is drawn or curve through the data so that it fits as well as possible, the more points cluster closely around the line of best fit, the stronger the relationship that exists between two variables (Rumsey, 2012).

To establish whether competition is one of the responses to globalization, a scatter plot diagram of the correlation of competition and globalization was plotted. 


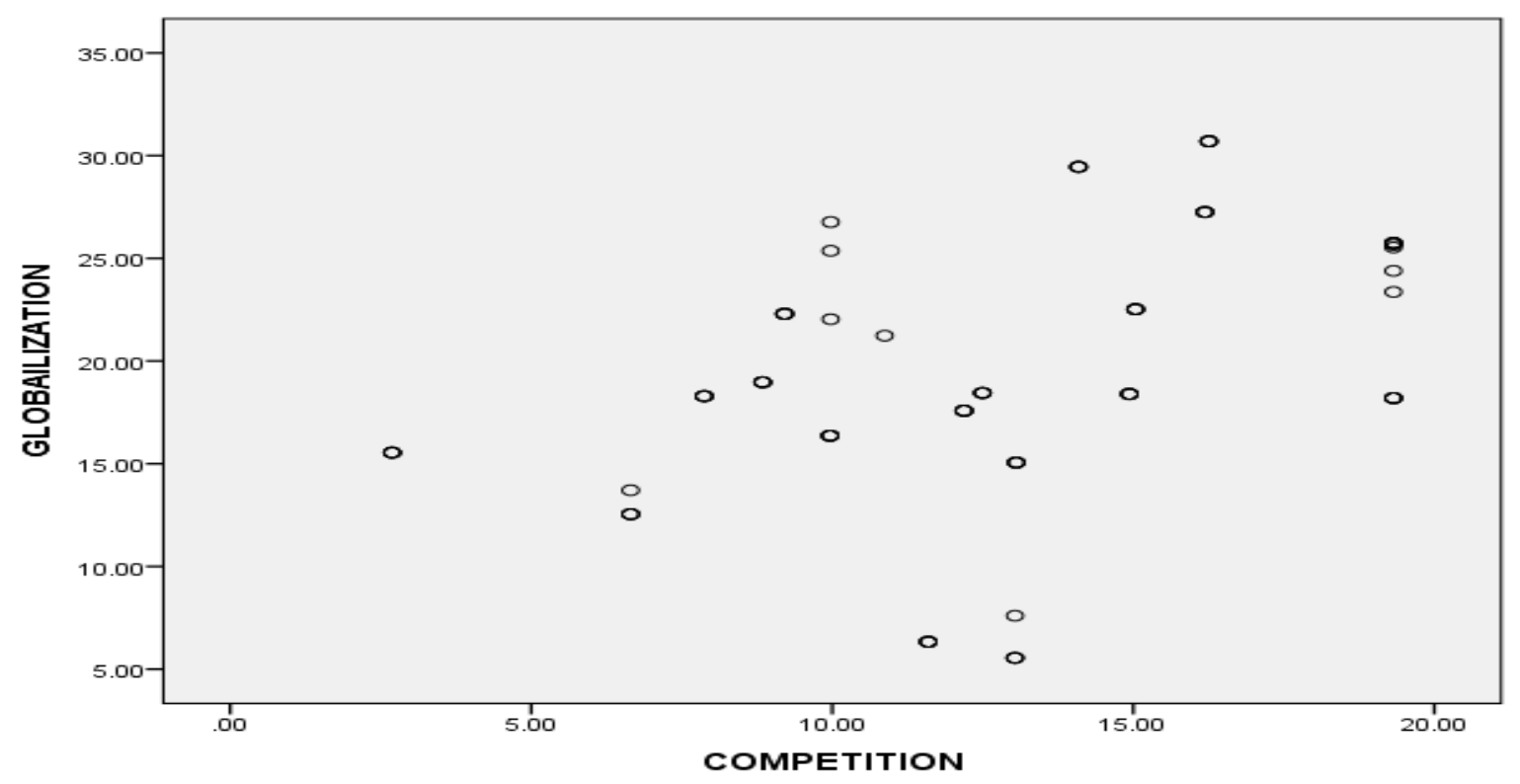

Figure 3. Competition as a response to globalization

Figure 3 shows a scatter plot diagram of correlation of competition versus globalization. As can be observed in the figure, all the points tend to concentrate from left to upper part of the diagram. These findings imply that there is a strong positive correlation between competition and globalization

The symmetric matrix with Pearson correlations given below in Table 5 shows that the Pearson correlation coefficient was 0.423 and this demonstrates that distribution chain have a positive correlation with globalization.

Table 5. Correlations

\begin{tabular}{llcc}
\hline & & GLOBAILIZATION & COMPETITION \\
\multirow{2}{*}{ GLOBAILIZATION } & Pearson Correlation & 1 & $.423^{* *}$ \\
& Sig. (2-tailed) & & .000 \\
& $\mathrm{~N}$ & 80 & 80 \\
& Pearson Correlation & $.423^{* *}$ & 1 \\
COMPETITION & Sig. (2-tailed) & .000 & 80 \\
& $\mathrm{~N}$ & 80 & \\
\hline
\end{tabular}

**. Correlation is significant at the 0.01 level (2-tailed).

\subsection{Regression Analysis}

Regression analysis was further carried out to establish the statistical significance between the study variables. Regression analysis was presented using regression model summary tables, Analysis Of Variance (ANOVA) table and beta coefficient tables.

\section{Regression Analysis on Competition and Globalization}

Regression analysis was done to determine the relationship between competition and globalization. 


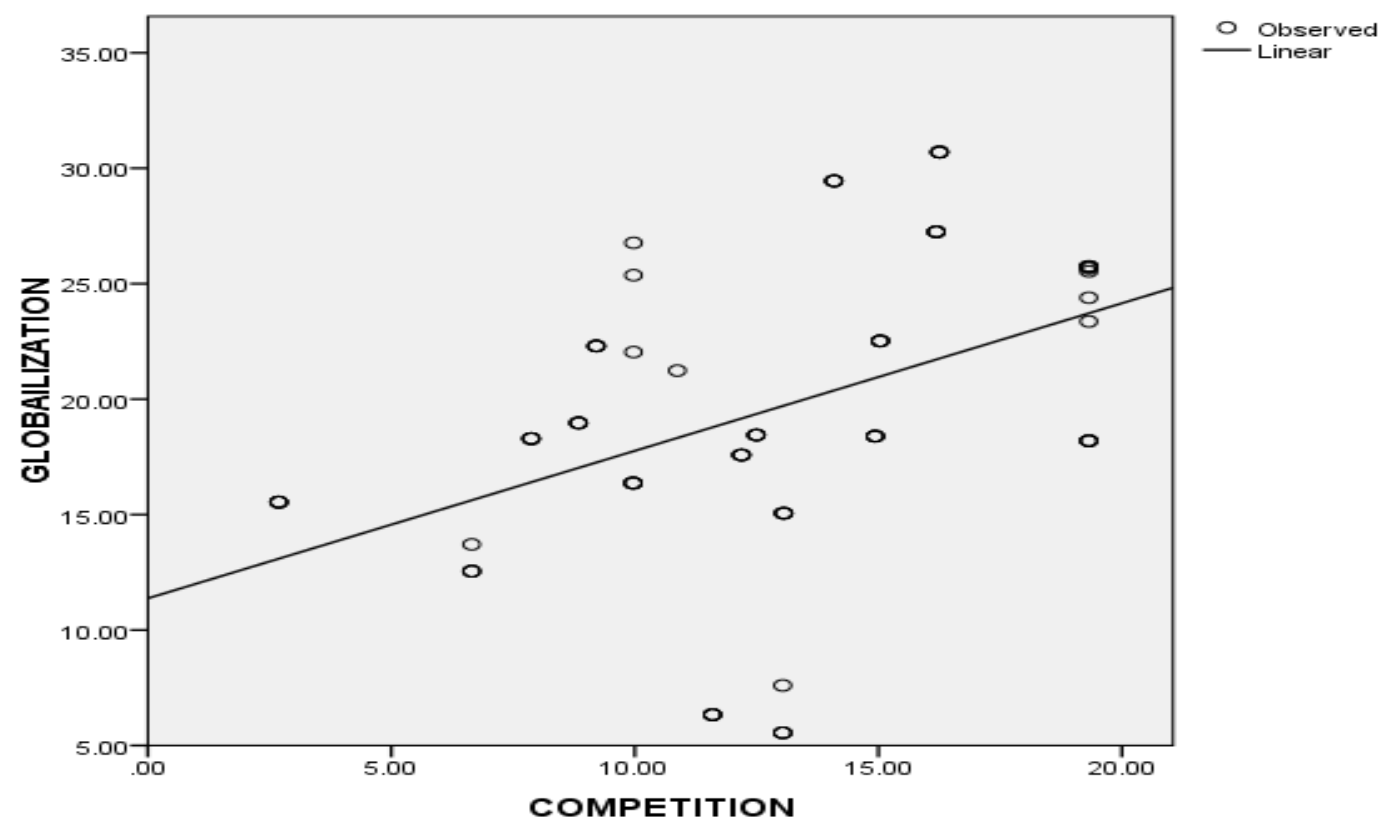

Figure 4. Regression analysis on competition and globalization

Table 6 shows that the coefficient of determination $\mathrm{R}$ square is 0.179 and $\mathrm{R}$ is 0.423 at 0.05 significant level. The coefficient of determination indicates that $17.9 \%$ of the variation in the response to globalization is explained by competition.

Table 6. Regression

\begin{tabular}{|c|c|c|c|c|}
\hline \multicolumn{5}{|c|}{ Model Summary } \\
\hline Model & $\mathrm{R}$ & R Square & Adjusted R Square & Std. Error of the Estimate \\
\hline 1 & $.423^{\mathrm{a}}$ & .179 & .169 & 5.97093 \\
\hline
\end{tabular}

a. Predictors: (Constant), COMPETITION

Table 7 presents the results of Analysis of Variance (ANOVA) on competition versus globalization. The ANOVA results for regression coefficient indicates that the significance of the $\mathrm{F}$ is 0.00 which is less than 0.05 hence implying that there is a positive significant relationship between competition and globalization.

Table 7. ANOVA ${ }^{\mathrm{a}}$

\begin{tabular}{llrrrrr}
\hline \multicolumn{7}{c}{ ANOVA $^{\mathbf{a}}$} \\
\hline Model & & Sum of Squares & df & Mean Square & F & \multicolumn{1}{c}{ Sig. } \\
& Regression & 606.821 & 1 & 606.821 & 17.021 & $.000^{\text {b }}$ \\
\cline { 2 - 7 } & Residual & 2780.859 & 78 & 35.652 & & \\
& Total & 3387.680 & 79 & & & \\
\hline
\end{tabular}

a. Dependent Variable: GLOBAILIZATION

b. Predictors: (Constant), COMPETITION

Further analysis determined beta coefficients of competition versus globalization. Table 8 shows that there is significant relationship between competition and globalization. Since the coefficient of competition is 0.639 which is statistically greater than zero. The $t$ statistic is 4.126 which is greater than zero. This demonstrates that competition have a positive influence on globalization. 
Table 8. Coefficients ${ }^{\mathrm{a}}$

\begin{tabular}{|c|c|c|c|c|c|}
\hline \multirow[t]{2}{*}{ Model } & \multicolumn{2}{|c|}{ Unstandardized Coefficients } & \multirow{2}{*}{$\begin{array}{c}\text { Standardized } \\
\text { Coefficients } \\
\text { Beta }\end{array}$} & \multirow[t]{2}{*}{$\mathrm{t}$} & \multirow[t]{2}{*}{ Sig. } \\
\hline & B & Std. Error & & & \\
\hline (Constant) & 11.372 & 2.065 & & 5.508 & .000 \\
\hline COMPETITION & .639 & .155 & .423 & 4.126 & .000 \\
\hline
\end{tabular}

a. Dependent Variable: GLOBAILIZATION

The alternative hypothesis that there is significant relationship between competition and globalization is the therefore accepted ( $\mathrm{P}$. value is 0.000 ). Thus, competition is used as a response to globalization.

\section{Discussion}

The factor analysis result on competition had a Cronbach's alpha of 0.834 . The study therefore deduced that all the competition indicators to be reliable in assessing competition as a response to globalization in the manufacturing firms in Kenya. All the competition indicators such as low cost strategy, exploring other markets, innovations and differentiation strategy were later used for further analysis.

Descriptive statistics result showed that $60 \%$ of the respondents indicated to a large extent $55 \%$ of the respondents indicated that to a large extent increasing the range of products produced is a competitive strategy of responding to globalization, $40 \%$ of the respondents indicated that to a very large extent innovations are competitive strategies of responding to globalization. According to Friedman (2006), globalization leads to increased competition due to the introduction of products from countries all around the globe with the ever-increasing lower prices. It used to be that firms would only compete against firms that were geographical close and of similar size. Now with globalization, companies are competing against other companies all around the globe and of all different sizes. From these findings, it is evident that one of the responses to globalization, which has been adopted by manufacturing firms in Kenya is competition.

Other competition related strategies adopted by manufacturing firms in Kenya to respond to globalization included: upgrading the website, corporate partnership with distributors around the globe \& branches in other African economies; infrastructure; information technology; social media marketing and branding; marketing segmentation; pricing strategies; market skimming; coming up with ISO friendly products and quality of goods. These findings are in line with the findings of a study done by Hannah and Camilla (2008) who found that MNCs use either a product brand strategy, or a corporate brand strategy to gain competitive advantage. However, there may be mixtures of the two types, but emphasis is typically on one of them. A product brand strategy is characteristically used when a company offers multiple products within different business segments, and when there are several different target groups. With a corporate brand strategy, the corporate name and the brand are the same. There is typically a master brand which has the same name as the corporation, and which may have additional sub-brands. It was found that the factors determining the branding strategy in international markets are stakeholder interests, corporate image and reputation, market complexity, as well as marketing costs.

Pearson correlation analysis of competition results gave a correlation of 0.423 , which demonstrated that competition has a positive correlation with globalization. Regression model of competition versus globalization gave a coefficient of determination of $\mathrm{R}$ square is 0.179 and $\mathrm{R}$ is 0.423 at 0.05 significant level. The coefficient of determination indicated that $17.9 \%$ of the response to globalization is explained by competition. This implies that there exists a strong positive relationship between competition and response to globalization.

\section{Summary of Findings}

On the relationship between competition and globalization in manufacturing firms in Kenya, the study found that $60 \%$ of the respondents indicated to a large extent exploring other markets is a competitive strategy of responding to globalization, $55 \%$ of the respondents indicated that to a large extent increasing the range of products produced is a competitive strategy of responding to globalization, $40 \%$ of the respondents indicated that to a very large extent innovations are competitive strategies of responding to globalization. The findings are in line with the findings by Friedman (2006) that globalization leads to increased competition due to the introduction of products from countries all around the globe with the ever-increasing lower prices. He added that in the past, firms would only compete against firms that were geographically close and of similar size. Now with globalization, companies are competing against other companies all around the globe and of all different sizes. 
The finding from correlation analysis showed that globalization has a positive relation with competition with a Pearson's Correlation Coefficient of 0.558 and 0.021 level of coefficient. The alternative hypothesis that there is significant relationship between competition and globalization is the therefore accepted (P. value is 0.000 ). Thus, competition is used as a response to globalization. These findings are in line with the findings by Aghion et al. (2005) who found that competition is expected to spur innovation by firms close to the efficient frontier (those with highest efficiency) while it discourages innovation by firms that are far from the frontier. Their predictions arose from a Schumpeterian model where incumbent firms that are closer to the frontier have an incentive to innovate when faced with potential (foreign) entrant in order to retain their market. Firms that are far from the frontier cannot compete with the more efficient entrant and competition simply reduces their expected benefits from innovation. Competition thus provides incentives for innovation for the more efficient domestic firms and a disincentive for the less efficient ones.

\section{Conclusions}

Competition was been found to be one of the key response strategies to globalization used by manufacturing firms in Kenya. Some aspects of competition strategies adopted by manufacturing firms in Kenya include: low cost strategy, exploring other markets, innovations and differentiation strategies. The findings of the study revealed that manufacturing firms in Kenya increase the range of products produced as a competitive response strategy to globalization. In line with these conclusions, the findings by other scholars reveal that globalization has led to increased competition due to the introduction of products from countries all around the globe with the ever-increasing lowering of prices. It used to be that firms would only compete against firms that were geographical close and of similar size. Now with globalization, companies are competing against other companies all around the globe and of all different sizes. The study thus concludes that competition is one of the key response strategies adopted by manufacturing firms in Kenya.

\section{Recommendations}

Manufacturing firms should reduce the direct cost such as energy while improving the market share. This can be done through innovation and outsourcing of functions which will be expensive to maintain within the organization. This will help in reducing the operation cost the giving the firms a competitive edge in the market. Manufacturing firms in Kenya should therefore any of the following four strategic postures to compete internationally: global standardization, internal strategy, localization strategy and transnational strategy to gain competitive advantage in the market.

\section{References}

Aghion, P., Robin, B., Stephen, R., \& Fabrizio, Z. (2005). Entry Liberalization and Inequality in Industrial Performance. Journal of European Economic Association, Papers and Proceedings, 3(2-3), 291-302.

Bernard, A. B., Jensen, J. B., \& Schott, P. K. (2006). Survival of the best .t: Exposure to low-wage countries and the (uneven) growth of US manufacturing plants. Journal of International Economics, 68(1), 219-237.

Bloom, N., Draca, M., \& Van-Reenen, J. (2008). Trade induced technical change? The impact of Chinese imports on IT and innovation. Mimeo. Mimeo.

Crossman, A. (2013). Convergence theory. About.com sociology. Retrieved December 04, 2013, from $\mathrm{http} / / /$ sociology.about.com/od/C_Index/g/Convergence-Theory.htm

Enz, C. A. (2010). Hospitality Strategic Management: Concepts and Cases (2nd Editio.). Hoboken, NJ: John Wiley \& Sons.

Ervin, J., \& Smith, Z. A. (2008). Globalization: A Reference Handbook. California: ABC-CLIO, Inc.

Firestone, M., Butler, S., Hardy, P., \& Karlin, A. (2009). Lonely Planet (e-Book Edi.). Nairobi, Kenya.

Friedman, TL. (2006). The World is Flat: A Brief History of the $21^{\text {st }}$ Century. Farrar, Stratus \& Giroux, New York.

Hair, J.F., Anderson, R.E., Tatham, R.L., \& Black, W.C. (1998). Multivariate data analysis with readings (5th ed.). Englewood Cliffs, NJ: Prentice-Hall.

Hanah, H., \& Camillah, C. (2008). Branding Strategies of MNCs in International Markets. Lulea University of Technology.

Hill, C., \& Jones, G. (2010). Strategic Management Theory: An Integrated Approach. Mason, OH: South-Western Learning. 
Honkala, C., Goldstein, R., Thul, E., Baptist, W., \& Grugan, P. (1999). Globalization and homelessness in the USA: Building a social movement to end poverty. Development in Practice, 9(5), 526-538.

Livesey, F. (2006). Defining High Value Manufacturing. University of Cambridge.

Miriga, J. (2010). Chinese Invasion Factor in Kenya and Africa. Retrieved August 20, 2012, from http://socioeconomicforum50.blogspot.com

Muhoro, M. W. (2011). An Assessment of the Impact of Globalization on Strategic Planning Practices at Standard Chartered Bank of Kenya. University of Nairobi.

Mussa, M. (2000). Factors Driving Global Economic Integration. In Jackson Hole, Wyoming symposium on Global Opportunities and Challenges.

Myatt, M. (2006). The Impact of Globalization on Business. Retrieved July 06, 2012, from http://www.n2growth.com/blog/the-impact-of-globalization-on-business/

Nyabiage, J. (2012, September 25). Raid of the continent by Chinese. Standard Digital.

Parker, B. (2005). Introduction To Globalization And Business: Relationships And Responsibilities. London: SAGE Publications.

Peltonen, T. A., Skala, M. R., Alvaro, S., \& Gabor, P. (2008). Imports and Pofitability in The Euro Area Manufacturing Sector The Role of Emerging Market Economies (No. 918).

Ray, L. J. (2007). Globalization and Everyday Life. Abington, OX: Routledge.

Rowbotham, M. (2000). Goodbye America! Globalization, debt and the dollar empire.

Roy, D. (2009). Strategic Foresight and Porter's Five Forces: Towards a Synthesis. Norderstedt: GRIN Verlag.

Sabirianova, K., Svejnar, J., \& Terrell, K. (2005). Foreign Investment, Corporate Ownership and Development: Are firms in emerging markets catching up to the world standard?

Tabachnick, B.G., \& Fidell, L.S. (2001). Using Multivariate Statistics. Boston: Allyn and Bacon.

Uslay, C. (2005). The Role of Pricing Strategy in Market Defense. Georgia Institute of Technology. 